\title{
ARTIKEL
}

\section{Meters maken: gedragsexperts in het lokaal bestuur}

\author{
Joram Feitsma
}

\begin{abstract}
Ambtenaren bij de Nederlandse overheden maken in toenemende mate gebruik van gedragswetenschappelijke inzichten in het beleidsproces. Deze inzichten zijn in eerste instantie vooral geagendeerd op het niveau van de rijksoverheid. Ze lijken echter ook bijzonder bruikbaar op lokaal niveau. Gedragsbewust beleid zet immers in op gedragsverandering via het herinrichten van de directe omgevingen van burgers, en juist lokale overheden hebben zicht en grip op deze omgevingen. In het licht van dit potentieel verkent dit artikel de huidige opkomst en institutionalisering van gedragsexpertise in het lokaal bestuur. De werkpraktijken van lokale gedragsexperts worden onderzocht aan de hand van drie dimensies van lokaal bestuur: positionering, praktijken en politiek. De bevindingen tonen aan dat lokale gedragsexperts zich nog in een experimenterende en opstartende fase bevinden, maar tegelijkertijd al met een rijkheid aan gedragsopgaven aan de slag zijn. Daarbij gaan ze tactisch om met schaarse middelen, weerstanden en schurende institutionele logica's.

Relevantie voor practitioners: het artikel laat zien dat (a) gedragsinzichten en -ontwerpen ook kansrijk zijn in het lokaal bestuur; (b) een lokaal bestuurlijk landschap van gedragsexpertise al aan het ontluiken is; (c) meters maken in het veld van gedragsexpertise vraagt om meerdere vormen van afstemming.
\end{abstract}

\section{Inleiding}

De toepassing van gedragswetenschappelijke inzichten in beleid staat hoog op de strategische agenda van de Nederlandse overheid (bijv. Ministerie van Economische Zaken, 2014; BIN NL, 2017). Onder intellectuele leiding van de WRR (2009; 2014; 2017) is een collectieve zoektocht gestart naar hoe gedragsinzichten van meerwaarde kunnen zijn in het maken van slim en effectief beleid dat rekening houdt met hoe burgers zich echt gedragen. Een onderdeel van die zoektocht is de vraag binnen welke locus van bestuur de meeste kansen liggen voor de benutting van gedragsexpertise. Tot nu toe is de aandacht vooral uitgegaan naar het niveau van de rijksoverheid (BIN NL, 2017; Schillemans \& De Vries, 2016; Feitsma, 2018a; Feitsma \& Schillemans, 2019), waar van nature veel aandacht bestaat voor strategische innovaties van het beleidsproces. In dit artikel verleg ik de focus naar een minder bekende, maar mogelijk kansrijke(re) bestuurslaag: de lokale overheid. Gedragsinzichten gaan in de kern over de bewustwording en benutting van de wijzen waarop burgers gestuurd worden door hun directe omgeving. Juist lokale ambtenaren hebben zicht en grip op die directe omgeving. Hoewel er nog weinig 


\section{Figuur 1 Shaming op de Erasmusbrug}

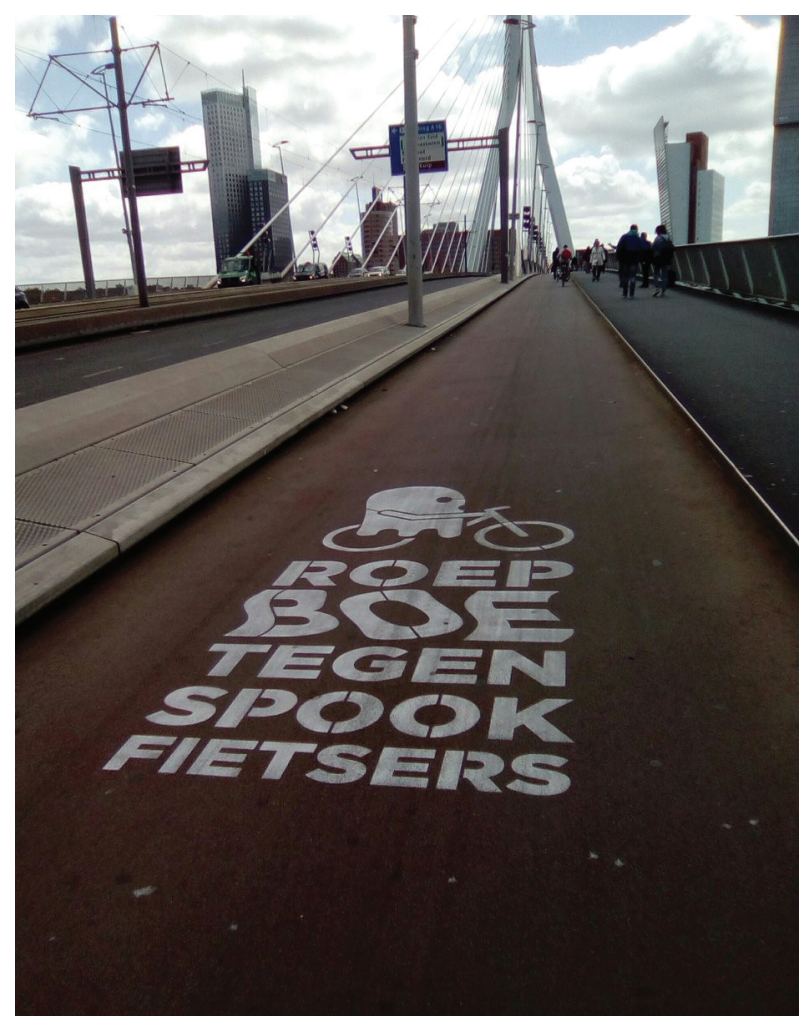

bekend is over lokaal gedragsbeleid, zijn er talloze aanwijzingen dat dit in opkomst is. Een recent voorbeeld (zie figuur 1; @Marielle1972, 2018) komt van Rotterdamse bodem, waar de gemeente zich in samenwerking met gedragswetenschappers inspande om spookrijden op de Erasmusbrug tegen te gaan. Via op het fietspad aangebrachte communicatie werd aangeroepen tot het 'boe roepen' tegen spookrijders, daarmee inspelend op de mens als sociaal dier die zeer gevoelig is voor (negatieve) oordelen uit de sociale omgeving. In de periode van onderzoek leverde deze shaming-techniek vijftig spookrijders minder op per dag (Algemeen Dagblad, 2018). Dit artikel verkent de opkomende bestuurspraktijk achter dit soort innovatieve gedragsinterventies. Het beschrijft de vroege ontwikkeling van gedragsexpertise in het Nederlandse lokaal bestuur. De onderzoeksvraag is: wat kunnen we van praktijken van pionierende lokale gedragsexperts leren over de kansen voor lokaal gedragsbeleid? 


\section{De opkomst van de sturende staat}

De Nederlandse ontwikkelingen rondom het toepassen van gedragswetenschappelijke inzichten passen in een internationale beleidsagenda, met voorlopers in Angelsaksische landen (Leggett, 2014; John, 2018; Whitehead e.a., 2017). Deze mondiale 'gedragswetenschappelijke draai' is niet in het minst te danken aan het boek Nudge (2008) van de Amerikaanse wetenschappers Richard Thaler en Cass Sunstein. Dit boek heeft inzichten uit de nieuwe school van de gedragseconomie toegankelijk gemaakt voor een breder publiek. Deze new school behavioural economics kwam op in de jaren zeventig en tachtig vanuit de wil van economen om in hun modellen beter rekenschap te kunnen geven van de manieren waarop menselijk gedrag afwijkt van de rationaliteitsnorm (Leggett, 2014). Gevoed door inzichten vanuit de cognitieve psychologie (bijv. Tversky \& Kahneman, 1974) identificeerden en structureerden gedragseconomen de voorspelbare wijzen waarop mensen afwijken van de homo economicus-norm. Inmiddels bestaat er een rijke catalogus van cognitive biases, waaronder het halo effect, sunk cost fallacy, optimism bias, confirmation bias en authority bias (Kahneman, 2011; zie Benson, 2016 voor een handzaam overzicht). Tezamen laten deze biases zien dat mensen zich in hun 'snelle', automatische, Systeem I-denken (Kahneman, 2011) veel meer laten sturen door hun fysieke en symbolische omgeving dan vaak wordt verondersteld.

De kracht van Nudge schuilt in zijn vermogen om deze gedragseconomische inzichten in de homo psychologicus te vertalen naar simpele manieren om beleid effectiever te maken. Hier komen we op het terrein van de zogeheten 'nudges', die de 'keuzearchitectuur' (Thaler \& Sunstein, 2008) zó vormgeven dat ze uitnodigt tot gewenst gedrag zonder daarbij juridische of financiële dwang uit te oefenen. Voorbeelden van dit soort subtiel verleidende nudges zijn overal te vinden, ook in Nederland - denk bijvoorbeeld aan de default-omdraaiing voor de registratie van orgaandonors (van opt-in naar opt-out), het aantrekkelijk plaatsen van gezonde producten in schoolkantines, en het afschermen van tabaksproducten aan de frontbalie in supermarkten. Het 'Behavioural Insights Team' (BIT UK) in Engeland, in 2010 opgericht als strategische eenheid onder het Cabinet Office, fungeert als voorloper in dit soort Nudge-interventies, en in het bijzonder in het experimenteel toetsen daarvan (BIT UK, 2012; 2014). Deze meer empirischwetenschappelijke werkwijze van BIT UK sluit naadloos aan op een bredere trend van evidence-based beleid (Parsons, 2002; Rouw, 2011).

De opkomst van gedragsbeleid is gepaard gegaan met een gepolariseerd, tamelijk verwarrend academisch debat. Aan de ene kant daarvan staan overtuigde pleitbezorgers, die vooral de belofte en ook de noodzaak zien van een meer effectief en tegelijkertijd minder dwingend beleid (bijv. Thaler \& Sunstein, 2008; John, 2018). Aan de andere kant staan critici, die vraagtekens zetten bij de epistemologische en morele agenda van gedragsbeleid. Belangrijke morele kritiekpunten stellen dat gedragsbeleid manipulatief en ondemocratisch zou zijn door de burger vooral op afstand via zijn automatische, onbewuste denken te willen beïnvloeden (bijv. White, 2013). Op epistemologisch vlak is een kritiekpunt dat gedragsbeleid 
gepaard gaat met een te nauwe focus op enkel cognitief-psychologische inzichten en experimentele methodologie. Ook wordt in gedragsbeleid een naïef maakbaarheidsdenken waargenomen (bijv. Lodge \& Wegrich, 2016). Daarmee zou het verworden tot een nieuwe vorm van 'gulzig bestuur' (Trommel, 2009), die vanuit een rationalistische hubris probeert de samenleving naar zijn hand te zetten. Behalve pleitbezorgers en critici bestaat er ook nog een groep van sceptici die zich afvraagt hoe omvangrijk, duurzaam en vernieuwend deze 'megatrend' nu daadwerkelijk is (bijv. Bonell e.a., 2011). De sceptici zien in Nudge vooral een opgepompte bestuurlijke fantasie, een vergankelijke hype met imposante ideeën maar uiteindelijk weinig substantie.

Deze verwarrende mix van tegenstrijdige analyses van gedragsbeleid - dat wil zeggen als utopie, dystopie en illusie - maakt de maatschappelijke implicaties ervan vooralsnog onzeker. In een poging om dit debat enigszins te ontwarren richt ik mij in dit artikel op een meer beschrijvende voorvraag: hoe komt deze trend eigenlijk op en tot welke concrete institutionele vormen leidt dit? Anders gezegd, dit artikel gaat over de institutionalisering van de gedragswetenschappelijke wending in beleid. Daarbij kijk ik, binnen de context van de Nederlandse overheid, vanuit het perspectief van de early adopters. Via het onderzoeken van lokale gedragsexperts en de aan hen verbonden ontluikende institutionele gedaanten probeer ik te leren hoe gedragsbeleid in de praktijk wordt ingebed en welke kansen en gevaren hier nu daadwerkelijk mee gepaard gaan. Dit artikel gaat dus niet zozeer over de metingen - de experimenten, nudges en uitkomsten daarvan maar eerder over de meters - de ambtenaren die zich profileren als 'gedragsexpert' - en het meters maken - hun institutionaliseringstraject, zoekende naar een stabiele en legitieme plek in het gevestigde beleidssysteem.

In Nederland bestaat er sinds het afgelopen decennium ruim aandacht voor het toepassen van gedragskennis, te zien aan een reeks invloedrijke adviesrapporten (bijv. WRR, 2009; 2014; 2017) alsook de reeds opgetuigde BITs en gedragsnetwerken bij bijvoorbeeld de Belastingdienst, de Autoriteit Consument en Markt, en de Ministeries van Economische Zaken en Klimaat en Infrastructuur en Waterstaat. Inmiddels is er ook een interdepartementaal Behavioural Insights Netwerk Nederland (BIN NL) actief, dat een agendabepalende en coördinerende rol op zich neemt (BIN NL, 2017). Dat ook Nederlandse bestuurskundigen en beleidswetenschappers de opkomende gedragsveranderende overheid op hun netvlies hebben staan, is onder andere terug te zien in het themanummer 'Gedragskennis in bestuur en beleid' in Bestuurskunde (Schillemans \& De Vries, 2016). Hierin werden onder andere voorbeelden van gedragsbewust beleid onder de loep genomen, ethische vraagstukken blootgelegd, en mogelijkheden verkend om gedragskennis verder te institutionaliseren. De meeste bestuurswetenschappelijke aandacht gaat uit naar gedragsinterventies als zodanig, en niet naar de opkomst en professionalisering van gedragskunde. Ook zijn de meeste studies gericht op gedragspraktijken op centraal overheidsniveau. Deze focus is mogelijk een gevolg van de topdown wijze waarop het gedragsthema in Nederland onder de aandacht is geko- 
men, in eerste instantie via het WRR-rapport De menselijke beslisser (2009) en een daaruit voortvloeiende interdepartementale kenniskamer.

\section{Lokale gedragsexpertise als terra incognita}

Een gevaar van bovengenoemde focus is dat een beeld wordt gecreëerd dat het Nederlandse gedragsbeleid vooral iets is van de rijksoverheid en zich bij uitstek leent voor een centraal georkestreerde, top-down benadering van beleid maken. Daarbij zou voorbij worden gegaan aan tal van nieuwe en spannende ontwikkelingen rondom het toepassen van gedragskennis die plaatsvinden op lokaal niveau (o.a. bij gemeenten, scholen, corporaties, zorginstellingen, koepelorganisaties). Ook daar zijn inmiddels voorbeelden te vinden van gedragspraktijken, zoals een 'Nudge Netwerk Utrecht' (gemeente Utrecht), 'Gedragsbeïnvloeder' (gemeente Hoorn), 'Duwtje-expert' (gemeente Deventer), 'Adviseur Gedragsbeïnvloeding' (gemeente Enschede), 'Nudge-adviseurs' (GGD Friesland) en een 'Behavioural Insights Group Rotterdam' (gemeente Rotterdam). Deze initiatieven zijn niet louter producten van een langzaam doorsijpelende top-down kennisagenda van het Rijk, maar vinden hun wortels veelal in concrete beleidsuitdagingen waarin innovatieve oplossingsrichtingen geboden waren.

Sterker nog, de inzet van gedragsexpertise is mogelijk juist op het lokale beleidsniveau kansrijk. Gedragsexpertise werkt namelijk via het psychologisch geïnformeerd 'sleutelen' aan de fysieke en informationele omgeving ('keuzearchitectuur') van burgers (Whitehead e.a., 2017). Lokale gedragsexperts lijken als keuzearchitecten in het voordeel in vergelijking met landelijk opererende gedragsexperts. Ze staan 'dichter op de burger' en hebben meer zicht en invloed op de directe leefomgevingen van burgers en hoe zij zich daarbinnen gedragen. Waar het directe contact tussen de rijksoverheid en de burger relatief beperkt en vooral van informationele aard is, met briefcommunicatie en overheidscampagnes als belangrijke directe contactpunten, bestaat er een uitgebreider contactgebied tussen de gemeentelijke overheid en de burger. Dat komt mede doordat gemeenten zorg dragen voor de inrichting van de lokale fysieke leefomgeving, waaraan allerlei gedragsnormen - denk bijvoorbeeld aan snelheidslimieten, parkeernormen en normen over de omgang met afval - zijn verbonden die zich lenen voor lokale keuzearchitectuur.

Het belang van gedragsexpertise op lokaal niveau lijkt ook zinvol tegen de achtergrond van beleidsverschuivingen in de afgelopen decennia van government naar governance, en van verzorgingsstaat naar participatiestad. Er vindt een kanteling plaats waarin steeds meer gecentreerde overheidsmacht wordt toegeschoven naar de gemeente als eerste overheid (Paardekooper e.a., 2013), en waarin tegelijkertijd burgers zelf steeds meer eigen verantwoordelijkheid wordt toegedicht in het bereiken van maatschappelijke doelen (Ossewaarde, 2007). De drie recente decentralisaties, waarin essentiële taken (zorg, werk en jeugdhulp) in het sociaal domein zijn overgeheveld van de rijksoverheid naar gemeenten, zijn illustratief hiervoor. Met deze verschuivingen neemt het lokaal bestuur een steeds belang- 
rijkere rol als keuzearchitect in. De vraag is echter wel of bewust en competent met deze rol wordt omgegaan, en of hiervoor de nodige hulpmiddelen, kennis en skills kunnen worden aangewend. Wat dit betreft zouden de lokale gedragsexperts met hun innovatieve psychologische bril en belofte van slim en effectief beleid uitkomst kunnen bieden.

Lokale gedragsexpertise lijkt daarmee op de terra incognita van gedragsbeleid: hoewel er volop kansen voor lokale gedragsexperts liggen om gedragsinzichten in te zetten, vormen ze tegelijkertijd een naar het lijkt kleine en onbekende groep, die nog maar weinig onderwerp is van een publiek, politiek en academisch debat. Om dit debat aan te wakkeren, en onderbouwd te kunnen delibereren over de kansen voor en grenzen aan lokaal gedragsbeleid, worden in dit artikel de werkpraktijken en institutionele gedaanten van lokale gedragsexperts verkend. De precieze wetenschappelijke relevantie van dit artikel bestaat daarmee in het empirisch blootleggen van een nog maar weinig verkend terrein van lokale gedragsexpertise - en het van daaruit doordenken over de daadwerkelijke kansen voor lokaal gedragsbeleid. In bredere zin biedt dit artikel inzicht in nieuwe ontwikkelingen in het samenspel tussen wetenschap en beleid, daarmee aansluitend op het klassieke bestuurskundige debat over de toepassing van wetenschappelijke kennis in de beleidspraktijk (Lindblom, 1959; Lindblom \& Cohen, 1979; Parsons, 2002).

Ik zal mijn verkenning maken aan de hand van een model met drie dimensies - positie, praktijken en politiek - waarlangs het lokaal bestuur kan worden gekenmerkt. De dimensie positie doelt op hoe lokale bestuurlijke actoren georganiseerd en gepositioneerd zijn binnen het beleidssysteem. De dimensie praktijken heeft betrekking op de dagelijkse activiteiten van lokale bestuurlijke actoren, de kennisbronnen en methoden en instrumenten die ze daarbij inzetten, en de resultaten die ze bereiken. De dimensie politiek duidt op de mate waarin het handelen van de overheid op dit niveau tot 'gedoe', conflicten en strijd leidt, en hoe omstreden kwesties doorwerken in het beleidsproces. Deze dimensies zijn ontleend aan Boogers en Schaap (2007), die stilstaan bij de wijze waarop de beschikbaarheid van interne en externe hulpbronnen en partners (positie) doorwerkt in lokaal beleid, alsook aan Barber (2013), die aangeeft hoe de soorten taken (praktijken) en het type bestuurscultuur (politiek) bepalend zijn voor lokaal beleid. Het model is ook ontleend aan Scherpenisse e.a. (2016), die de strategische vraagstukken rondom het inrichten van een gedragspraktijk onderverdelen in keuzes over positionering, projecten, prestaties en professionaliteit (positie en praktijken). Tabel 1 vat de drie dimensies - die als sensitizing concepts worden gehanteerd - kort samen.

\section{Methode}

Om de opkomst van lokale gedragsexpertise in detail te kunnen bestuderen, en tegelijkertijd oog te houden voor haar verschillende verschijningsvormen, heb ik een 'step-in, step-out'-type (Madden, 2017) etnografisch veldwerk verricht 
Tabel 1 Drie dimensies van lokale gedragspraktijken (ontleend aan Boogers \& Schaap, 2007; Barber, 2013; Scherpenisse e.a., 2016)

\begin{tabular}{|c|c|c|c|}
\hline Dimensie & Positie & Praktijken & Politiek \\
\hline Aspecten & $\begin{array}{l}\text { Interne positionering } \\
\text { Beschikbare capaciteiten } \\
\text { Externe kennisinfrastruc- } \\
\text { tuur }\end{array}$ & $\begin{array}{l}\text { Taken en toepassingsgebie- } \\
\text { den } \\
\text { Activiteiten, outputs en out- } \\
\text { comes } \\
\text { Kennisbronnen en -metho- } \\
\text { den }\end{array}$ & $\begin{array}{l}\text { Bestuurlijke cultuur } \\
\text { Strijd, conflict } \\
\text { Weerstanden }\end{array}$ \\
\hline
\end{tabular}

(Rhodes e.a., 2007). Tijdens een periode van zeventien maanden (november 2016 tot en met maart 2018) heb ik me dicht op de alledaagse leefwereld van verscheidene lokale gedragsexperts begeven. Ik heb hen gedurende een relatief langere tijd en in hun professionele omgeving bestudeerd, en niet alleen van buitenaf ('frontstage') bevraagd, maar ook van binnenuit ('backstage') geobserveerd. Deze etnografische werkwijze helpt inzichtelijk te maken hoe het er 'echt' aan toegaat binnen organisaties (Van Hulst, 2008). Concreet heb ik drie methoden gebruikt:

- participatieve observaties op 11 verschillende momenten, in totaal 19 uur:

- 4 observaties waarin ik een interne educatieve bijeenkomst bijwoonde;

- 4 observaties waarin ik een intergemeentelijke kennisuitwisselingsbijeenkomst bijwoonde;

- 1 observatie waarin ik meehielp bij de uitvoering van een veldexperiment;

- 1 observatie waarin ik bijdroeg aan een gedragsveranderingscursus voor een gemeenteafdeling;

- 1 observatie waarin ik meedacht met een BIT over de interne organisatie van gedragskennis;

- semigestructureerde interviews met 15 lokale actoren, overwegend gedragsexperts:

- 11 ambtenaren bij 8 verschillende gemeenten (Utrecht, Amsterdam, Rotterdam, Den Haag, Enschede, Deventer, Leeuwarden en Hoorn);

- 2 ambtenaren bij intergemeentelijke koepelorganisaties (Vereniging van Nederlandse Gemeenten (VNG) en Divosa);

- 1 wethouder;

- 1 schooldirecteur;

- documentenanalyse van memo's, e-mailcorrespondentie en online content.

Waarnemingen, initiële inzichten en analyses op basis van de observaties en documentenstudie zijn verwerkt in veldnotities. Enkele van die veldnotities zijn later in meer detail uitgewerkt om te presenteren in dit artikel. De semigestructureerde interviews zijn opgenomen, selectief getranscribeerd en, tezamen met de veldnotities, in een iteratief proces gecodeerd op basis van de sensitizing concepts uit tabel 1. Deze concepten vormden een generiek ordeningsmechanisme bij het analyseren van de empirische data. Binnen deze generieke structuur - met als hoofdcodes positie, praktijken en politiek - zijn tijdens het coderingsproces subcodes opgesteld vanuit de empirische data. Bijvoorbeeld, bij het analyseren van het empirisch materiaal in relatie tot de hoofdcode positie werden bepaalde terugke- 
rende dimensies zichtbaar - zoals 'centrale gedragseenheid versus netwerkbenadering' - die als subcodes zijn aangehouden. De hier gepresenteerde analyse is uitgewerkt aan de hand van deze hoofd- en subcodes en hieraan verbonden observaties rondom bijvoorbeeld saillante zienswijzen, overeenkomsten of juist verschillen in het veld.

Een belangrijke vraag qua onderzoeksdesign is: wanneer is iemand eigenlijk een 'gedragsexpert'? Deze vraag is niet eenduidig te beantwoorden, gegeven de hybride historie van gedragsbeleid. Zo zou je op meer impliciet niveau de meeste sociale wetenschappers alsook veel ambtenaren met kennis van de lokale bevolking in zekere zin als 'gedragsexperts' kunnen beschouwen. En ook meer expliciet bestaat er al een langere traditie om gedragswetenschappelijke inzichten toe te passen op lokaal niveau. Daarbij kan worden gedacht aan het gebruik van sociaalpsychologische interventietechnieken in domeinen zoals gemeentevoorlichting, jeugdzorg, handhaving, diftar en de gemeentelijke gezondheidszorg (GGD). Tegelijkertijd heeft Nudge wel degelijk een nieuwe impuls gegeven aan het toepassen van gedragswetenschappen: een impuls die ook gestut is op een distinctief type gedragsinzichten, namelijk hoofdzakelijk die uit de nieuwe school van de gedragseconomie - waarin het biases and heuristics-onderzoeksprogramma centraal staat. Het is precies deze, meest recente impuls waar dit artikel zich op richt. Daarbij ga ik op zoek naar degenen die zichzelf identificeren als vaandeldragers van deze impuls: de zelfbenoemde 'Nudge-experts' en 'Behavioural Insights Teams'. Ik definieer 'gedragsexperts' als bestuurlijke actoren die nieuwe gedragseconomische inzichten expliciet en structureel toepassen, en zichzelf presenteren als vaandeldrager van deze trend. Deze vaandeldragers vormen als nieuwe professionele gemeenschap de meest directe vertegenwoordiging van de huidige Nudge-impuls, en zijn daarmee een relevant studieobject om deze impuls beter te begrijpen.

Bepalend voor het selectieproces van respondenten en observatiemogelijkheden was dat lokale gedragsexperts een vrij nieuwe en gefragmenteerde groep vormen. Een gebrek aan publieke documentatie maakte dat ik overwegend een pragmatische selectiebenadering heb gevolgd, gestuurd door waar ik activiteiten in het veld aantrof. Ik ben mijn veldstudie gestart vanuit mijn eigen netwerk, bij een Utrechtse gedragsexpert die initiatiefnemer was van het 'Nudge Netwerk Utrecht' alsook van een intergemeentelijk G6-overleg rondom de 'Inzet op gedrag'. Vanuit dat contact en de daaruit voortvloeiende interviews, participatieve observaties en uitnodigingen voor bijeenkomsten heb ik met behulp van de sneeuwbaltechniek en verifiërend bureauonderzoek andere lokale gedragsexperts opgespoord. Daar waar ik in mijn zoekproces structurele activiteit rondom gedragskennis kon identificeren, heb ik ook met lokale gedragsexperts gesproken - op Joure, Eindhoven en Tilburg na. De selectie betreft vooral gedragsexperts die actief zijn in relatief grotere gemeenten in stedelijke gebieden. Dit is in lijn met het idee dat lokale overheden met meer beleidscapaciteit eerder geneigd zijn om te experimenteren met beleidsinnovaties (Shipan \& Volden, 2012). Naast gedragsexperts uit verschillende gemeenten heb ik ook verschillende typen van lokale bestuurlijke actoren bestudeerd. 


\section{Bevindingen}

\subsection{Verkenningen in het lokale gedragslandschap}

Het lokale gedragslandschap is voorzichtig aan het ontluiken. In het afgelopen decennium zijn gedragsteams, -netwerken, en -functies ontstaan in diverse (inter)gemeentelijke en lokale maatschappelijke organisaties. De Randstedelijke gemeenten lijken het voortouw te nemen wat deze ontwikkelingen betreft. Hoewel lokale gedragsexperts verenigd zijn in het breed uitdragen van een sterk rationalistische boodschap - dat wil zeggen beogend om meer effectief beleid te maken met behulp van nieuwe gedragsinzichten -, vormen ze tegelijkertijd een gefragmenteerde groep. Zo zijn ze actief op een breed aantal beleidsdomeinen, bijvoorbeeld publieke gezondheid, communicatie, afval, toezicht en handhaving, werk en inkomen, en schuld en armoede. Ook qua professionele achtergronden is de groep heterogeen, variërend van respondenten die nog vrij onbekend zijn met gedragsbeïnvloeding in het publieke domein tot respondenten die ruime praktijkervaring en academische kennis bezitten rondom dit thema. Respondenten met meer geavanceerde expertise hebben bijvoorbeeld gedragsbeïnvloeding-gerelateerde masterclasses of een gedragswetenschappelijke studie zoals sociale psychologie gevolgd. Een voorbeeld van een praktijk waaraan aanzienlijke hardcore gedragswetenschappelijke expertise verbonden is, is de Rotterdamse gedragseenheid, met een professor in de gezondheidspsychologie, die functioneert als trekker vanuit de universiteit, en teamleden met specialisaties in onder andere gezondheidswetenschappen, psychologie en antropologie (Website BIG'R, 2018).

Het verkennende en heterogene karakter van het lokale gedragslandschap maakt dat gedragsexperts zelf nog bezig zijn zicht te krijgen op wie er binnen en buiten hun gemeenten met de gedragsthematiek bezig zijn. Veel verbindingen komen op toevallige en incrementele wijze tot stand, en er wordt in 'eilandjes' gewerkt. Zoals een respondent stelt: 'We kennen elkaar steeds meer door toevallige contacten. Via via hoor je: "Die is er ook mee bezig, die heeft een project gedaan." Dat soort dingen. En nog bijna iedere week spreek ik nieuwe collega's die er dus ook iets mee doen. Gister nog.' Wel worden er pogingen gedaan om meer structurele verbindingen tussen en binnen gemeenten te leggen. Zo is het intergemeentelijke G6-overleg rondom 'De inzet op gedrag' opgericht, waarin beginnende gedragsexperts in de gemeente Utrecht, Amsterdam, Eindhoven, Tilburg, Rotterdam en Den Haag kennis en ervaringen delen. Ik ben bij enkele van deze G6-overleggen aanwezig geweest. Deze bleken bijzonder betekenisvol te zijn. In de presentaties die gedragsexperts aan elkaar gaven en de gesprekken die ontstonden, kwam een breed aantal aspecten van het werk van gedragsexperts aan het licht. Het observeren van een dergelijk intergemeentelijk overleg hielp bovendien om in kaart te brengen waarin de benaderingen van de afzonderlijke gemeenten verschillen en overeenkomen.

Om het lokale gedragslandschap verder te analyseren zal ik de drie dimensies van positie, praktijken en politiek nalopen. Deze analyse wordt in belangrijke mate opgehangen aan een gereconstrueerde observatie van zo'n bovengenoemd intergemeentelijk overleg, namelijk het derde G6-overleg in maart 2018 in het stad- 
huis van Rotterdam. Deze bijeenkomst vond niet toevallig in Rotterdam plaats, want daar is op het moment van onderzoek veruit de grootste lokale gedragseenheid te vinden. De gepresenteerde observaties van dit overleg zijn later uitgewerkte fragmenten op basis van een initiële grove veldnotitie. Deze fragmenten zijn licht bewerkt op leesbaarheid en relevantie in het licht van de sensitizing topics (zie tabel 1). Het uitvergroten van één enkel observatiemoment helpt om de lokale gedragspraktijk met al haar bijzonderheden van dichtbij te zien. Tegelijkertijd wordt de analyse, waar relevant, ondersteund met andere empirische data, om zo ook oog te houden voor hoe de lokale gedragspraktijk zich manifesteert in de breedte.

\subsection{Positie}

De analyse kijkt allereerst naar de positionering van gedragsexpertise op lokaal niveau.

De voorzitter opent de vergadering. De experts uit Amsterdam en Eindhoven zijn verhinderd. Op de agenda staan vier presentaties, voorafgegaan door een korte introductie van een lid van 'Behavioural Insights Group Rotterdam' (BIG'R).

Het BIG'R-lid vertelt over het type projecten waarmee zijn team bezig is, zoals parkeren, publieke gezondheid en uitgaansoverlast. 'Bij de gemeente zit je toch meer met aardse zaken waar je mee te maken krijgt. En van de gemeente krijgen we de vraag terug van: "Kunnen we daar dan niet iets mee?"' Het BIG'R-lid ziet dat er verschillende benaderingen gehanteerd worden door gemeentelijke gedragsexperts. De een gaat voor het inhuren van externe gedragsbureaus. De ander pakt het zelf heel grondig aan. Hij doet een oproep om hier met elkaar te delen wat werkt, 'Dus nu de vraag: kunnen we niet met elkaar wat dingen delen zodat we hier niet in eenzame positie mee bezig zijn? En als iets niet werkt? Laat het dan grandioos mislukken zodat anderen niet dezelfde fout hoeven te maken.'

Het BIG'R-lid vertelt dat ze voor vier jaar tijd een budget van $€ 1$ miljoen hebben gekregen voor een samenwerking met de Erasmus Universiteit Rotterdam. 'Wij kopen twee onderzoekers van Erasmus Universiteit. En die staan niet op afstand', zegt hij terwijl hij wijst naar de twee personen naast hem. 'Zij zitten hier. Ruim een jaar geleden startten we met 4 a4'tjes, zoekend naar projecten, en nu zijn we met 25 parttime en fulltime mensen. We hebben een infrastructuur, een aantal onderwerpen, en zijn klaar om stappen te makken.' De BIG'R-aanpak is inmiddels verder geformaliseerd, telkens toewerkend naar een eindproduct dat kan variëren van ad hoc collegiale consultatie tot het optuigen van grotere casussen met extensief gedragsonderzoek.

De Haagse gedragsexpert is aan de beurt om te presenteren. Ze vertelt dat Den Haag zich nog in een opstartfase bevindt met betrekking tot het gemeentebreed en structureel toepassen van gedragskennis. De benadering is nu vooral nog het werken met extern ingehuurde bureaus geweest. 'Maar we willen er steeds meer naar toe dat we die kennis in huis halen.' Het is nog een uitdaging om gedragsexpertise 'naar een hoger niveau te brengen. Er is nog te weinig kennis, te weinig tijd, te wei- 
nig handvatten, en te weinig geld om hier mee aan de slag te gaan.' Tot nu toe heeft ze voornamelijk geïnvesteerd in het opbouwen van een netwerk, het beginnen van een samenwerking met de universiteit en het ophalen van casussen. Ze zegt al wel na te denken over hoe gedragsinzichten in de toekomst gemeentebreed toegepast kunnen worden, mogelijk via een 'expertiseteam'. Inmiddels is een groep van circa twintig mensen, werkzaam op verschillende beleidsniveaus (managers, beleidsmakers, uitvoerders), geïnteresseerd om hier gemeentebreed mee verder te gaan.

De Utrechtse gedragsexpert begint met te vertellen dat Utrecht geen formele BIT heeft. Wel hebben hij en een collega in de eigen tijd allerlei activiteiten rondom het thema georganiseerd. Zo worden er nu in tien duo's door gemeentemedewerkers masterclasses in gedragsbeïnvloeding gevolgd. Ook willen ze graag 1.0 fte ruimte creëren voor het thema om 'bij te houden wat er allemaal gebeurt'. Het accent ligt dus op een decentrale aanpak. 'I $k$ wil het van ons af organiseren en zorgen dat organisatieonderdelen hier zelf mee aan de slag gaan. Het liefst maak ik mezelf overbodig en pakken collega's het zelf op. Binnen mijn eigen organisatieonderdeel is dit al aardig gelukt. Dat is precies wat ik eigenlijk wil. Ik weet toch niks van de [beleids]inhoud. Lekker organisch werken.'

Een van de Rotterdamse gedragsexperts vraagt aan de Utrechtse collega: 'Hebben jullie al veel mensen met expertise rondlopen? En hoe zorgen jullie dat mensen daadwerkelijk met voldoende bagage aan de slag gaan met projecten? Onze ervaring is dat je mensen wel getriggerd krijgt, maar om ze daadwerkelijk de vertaling te laten maken naar beleid dat leidt tot gedragsbeïnvloeding... daar is wel iets meer voor nodig dan een cursusje.' De Utrechtse gedragsexpert: 'Dat hangt er vanaf wat je met "expertise" bedoelt. Als je mensen met enige kennis van zaken bedoelt, dat zijn er tientallen. En met die cursussen heb ik echt wel het idee dat er een aantal collega's zijn die hier enthousiast van blijven en dat er borging is. Maar echte "experts"... daar hebben we er geen een van."

De veldnotitie wijst op een aantal interessante aspecten. Allereerst zien we dat er veel expliciete aandacht bestaat voor positionering, netwerkvorming en verdere institutionalisering. Er worden stappen gezet om verschillende eenheden, netwerken en initiatieven verder te stroomlijnen en te verankeren in het bestaande overheidsbestel. Het periodiek samenkomen in een intergemeentelijk G6-netwerk is hier een treffend voorbeeld van. Maar ook intern zijn gedragsexperts aan het experimenteren met passende organisatievormen voor het toepassen van gedragsexpertise. Hierin worden verschillende benaderingen zichtbaar. Vooralsnog lijkt het erop dat de meeste lokale gedragsexperts kiezen voor een 'netwerkbenadering' waarin bestaande gedragspraktijken los opereren, maar wel onderdeel vormen van een samenhangend netwerk. Hierin zijn gemeentelijke gedragsexperts als (tijdelijke) 'aanjagers' actief.

De keuze voor deze netwerkbenadering lijkt deels een gevolg te zijn van de verkennende fase waarin veel lokale gedragsexperts zitten, nog volop bezig met het überhaupt in kaart brengen van de huidige stand van zaken rondom de intraorganisationele toepassing van gedragsinzichten. Dat geldt bijvoorbeeld voor de 
Haagse gedragsexpert, die meldt dat ze inmiddels een 'team met geïnteresseerden' heeft gevormd en daarmee recent voor het eerst bijeen is gekomen. Verder dan dit is het nog niet geformaliseerd. Naast deze netwerkbenadering zijn er ook bescheiden bewegingen richting het formaliseren en concentreren van gedragsexpertise. Hiermee wordt het model van BIT UK gevolgd, dat destijds opgericht is als formele en autonome eenheid. De gemeente Amsterdam heeft bijvoorbeeld een gemeentebrede 'Gedragsdeskundige' in dienst en de gemeente Enschede een 'Adviseur Gedragsbeïnvloeding' die fulltime gedragsinzichten inzet. In termen van capaciteit en budget valt ook de relatief ambitieuze aanpak van de gemeente Rotterdam op, waar een formeel gedragsteam met inmiddels 25 leden is opgetuigd in samenwerking met de Erasmus Universiteit Rotterdam.

De meeste lokale gedragsexperts geven aan dat de beperkte hoeveelheid beschikbare hulpmiddelen een uitdaging vormt. Er is meestal weinig formele gedragswetenschappelijke expertise in huis, en gebrek aan tijd en middelen maakt het moeilijk om projecten op kwalitatief hoog niveau uit te voeren. Dit lijkt vooral te gelden voor de grotere groep van gedragsexperts van wie de activiteiten rondom gedragsexpertise geen onderdeel uitmaken van het reguliere takenpakket. Een gedragsexpert vertelde tijdens een veldobservatie dat het ontmoedigend kan werken als constant anderen moeten worden gemotiveerd en er geen formalisatie komt. Maar ook de meer geformaliseerde en gecentraliseerde gedragseenheden zijn - in het grotere institutionele plaatje - vooralsnog slechts een kleine speler met weinig capaciteit. Wat dit betreft is een voordeel van het werken via een decentrale netwerkbenadering dat lokale gedragsexperts kunnen aanhaken bij reeds bestaande projecten en bijbehorende capaciteiten en budgetten. Een gedragsexpert noemde dat als hij aansloot op de inhoudelijke projecten en interesses van budgethouders of projecthouders binnen de gemeente (in zijn geval bijvoorbeeld rondom spitsmijdingen of het verminderen van houtstook), hij dan onderdeel werd van de projectmiddelen en er zo 'middelen in overvloed' waren.

Lokale gedragsexperts zoeken veel samenwerking met externe kennispartners. Ze halen kennis en vaardigheden op door onderlinge uitwisselingen met een extern netwerk van wetenschappers, consultancybureaus en internationale beleidsagentschappen. Belangrijke expertisepartners die onderzoeken uitvoeren en trainingen verzorgen, zijn onder andere Duwtje, Dijksterhuis \& Van Baaren, BIT UK, de Erasmus Universiteit Rotterdam en de Universiteit Utrecht (ook ikzelf ben als Utrechtse onderzoeker betrokken geweest bij lokale samenwerkingen). Zoals de veldnotitie laat zien, bestaat er wel een duidelijke wil om meer eigen expertise te ontwikkelen, bijvoorbeeld door gemeenteambtenaren intern masterclasses te laten volgen. Tegelijkertijd wordt ook de vraag opgeworpen of dat voldoende is, en of er niet intensiever moet worden geïnvesteerd in interne gedragsexpertise.

Samenvattend: de toepassing van gedragsexpertise bij de meeste gemeenten oogt nogal diffuus, en is meestal verspreid over los samenhangende projecten. Ook valt op dat de toepassing deels is geëxternaliseerd, gezien de intensieve samenwerking met externe gedragsbureaus en universiteiten. Op die plekken waar gedragsexpertise meer wordt geconcentreerd en geformaliseerd lijkt een toename 
in eigen slagkracht zichtbaar. Een gemeentelijke BIT - zoals BIG'R in Rotterdam kan functioneren als een centrale plek waar kennis en middelen samenkomen. Dit geeft het abstracte idee van 'de toepassing van gedragsinzichten' een concrete institutionele vorm. Bovendien draagt het bij aan verdere verzelfstandiging, internalisering en borging van gedragsexpertise. Toch past een netwerkbenadering, hoewel diffuser en lastiger zichtbaar, volgens sommige gedragsexperts beter. Dit is omdat deze benadering beter gebruik maakt van bestaande initiatieven en, zoals een respondent stelde, 'er een groter gevoel van eigenaarschap ontstaat. Als er een centrale unit is, dan "zijn zij er van" en hoef ik er dus niks meer mee te doen, zogezegd.' Deze positioneringskwestie werd kernachtig verwoord als het dilemma van 'vindbaarheid versus eigenaarschap'.

Verder valt ook op dat de wijze waarop gedragsexpertise een plek krijgt in de verschillende gemeenten, en het potentieel dat daaruit spreekt, voortvloeit uit bijzondere aspecten van de lokale omgeving. Bijvoorbeeld, de nabijheid van een grote universiteit met expertise en ambities op het gebied van gedragsverandering lijken kansen te scheppen, zoals te zien in de intensieve Rotterdamse samenwerking met de Erasmus Universiteit en het Utrechtse Living Lab. Überhaupt lijken de grootstedelijke gemeenten beter in staat om plek te bieden aan gedragsexpertise, daar zij veelal meer ruimte voor strategische innovatie hebben, zelf meer kennis bezitten, en ook dichter omringd zijn met externe kennispartners. Verder lijkt de invloed van de lokale bestuurscultuur zichtbaar in hoe gedragsexpertise wordt georganiseerd. De typisch Rotterdamse bestuurscultuur van 'doorpakken' lijkt bijvoorbeeld door te werken in het oprichtingsverhaal van BIG’R, dat relatief voortvarend geïnstitutionaliseerd is en capaciteit heeft opgebouwd.

\subsection{Praktijken}

De analyse beweegt nu naar een focus op praktijken, zoals de werkvelden, werkwijzen en activiteiten van lokale gedragsexperts.

De Haagse gedragsexpert vertelt over de gedragscasussen die spelen in haar gemeente. Die blijken talrijk: gedragsinzichten zijn intern reeds toegepast binnen diverse beleidsopgaven, bijvoorbeeld rondom ondergrondse restafvalcontainers, uitstroom 50+, woninginbraken, mobility mentoring en gezonde broodtrommels. En op de planning staan onderwerpen zoals fietsparkeren, brieven, illegaal woningverhuur, no-shows bij burgerafspraken, heling, zakkenrollers en overlast door hondenpoep.

Een Rotterdamse gedragsexpert, ook lid van BIG'R, vertelt over een volgens hem 'atypische' case. Bij een nieuw geopend zwembad in de stad bestond de verwachting dat er in de publiek toegankelijke ingang een kans was op ongewenst gedrag (zoals 'hangen', baldadigheid, graffiti, drugsgebruik, slapen door daklozen) zonder dat daarop toezicht mogelijk was. Zulk ongewenst gedrag zou bezoekers aan het zwembad kunnen afschrikken of een onaangename ervaring kunnen bezorgen. De kans op ongewenst gedrag heeft te maken met dat het zwembad op de eerste verdieping ligt, en dat de ingang hier niet direct toegang toe geeft. BIG'R heeft gekeken hoe de 
kans op ongewenst gedrag zou kunnen worden verkleind. BIG'R-projectleden hebben een intern wetenschappelijk medewerker op dit project gezet, zijn een paar keer gaan observeren op locatie, en zijn gesprekken aangegaan - bijvoorbeeld met de architect, exploitanten en de gebiedsmanager. Ze hebben vervolgens gebrainstormd over interventies vanuit de theorie van 'defensible space', die nadruk legt op het creëren van natuurlijke surveillance, zichtbaarheid en constante doorstroom om sociaal gedrag in de publieke ruimte te reguleren (Website BIG'R, 2018). Vanuit deze theorie heeft BIG'R geadviseerd om in te zetten op het transparant maken van de ruimte en het benadrukken van het gevoel van 'menselijke aanwezigheid'. Belangrijke adviezen - die inmiddels zijn gerealiseerd - waren om qua architectuur zo veel mogelijk met glas te werken. Zo zijn de liftschacht en onderdelen van de ingang volledig van glas gemaakt - een impactvolle, maar ook 'kostbare mutatie'. BIG'R denkt verder ook na over hoe op gedrag kan worden ingespeeld via beeld, licht, geluid en reuk. De Rotterdamse gedragsexpert legt uit: 'Als we kijken naar welke zintuigen er zijn... zien, horen, ruiken - met proeven valt dan misschien even niks te doen - dan blijkt dat er allerlei zintuiglijke routes interessant zijn om gedrag te beïnvloeden.' Ideeën van BIG'R zijn om 'zwembadgeluiden' weer te geven, om mensen af te beelden op de muur, en om met verlichting te werken die de weerschijn van water suggereert - om zo een uitnodigende 'atmosfeer' te creëren die de doorstroom naar het zwembad bevordert (Website BIG'R, 2018). Nog een ander geopperd idee is om een geursysteem met chloorlucht te installeren. Deze ideeën worden vooralsnog achter de hand gehouden door BIG'R, aangezien er op het moment van onderzoeken geen aanleiding bestond ze te gebruiken: sinds de opening van het zwembad in januari is de gevreesde overlast uitgebleven.

Wat in bovenstaande veldnotitie als eerste opvalt, is de rijkheid aan geïdentificeerde opgaven voor gedragsverandering. Dat zijn vaak 'hele platte dingen', zoals het tegengaan van overlast door verkeerd geparkeerde fietsen. Volgens gedragsexperts lukt het gemeenten bij veel van dit soort zaken nog niet om burgers de gewenste kant op te sturen. Experts in de hoek van communicatie, afval en publieke gezondheid noemen bijvoorbeeld dat een dominante rationeel informerende beleidsaanpak onvoldoende gedragsverandering bewerkstelligt. Experts in de hoek van toezicht en handhaving en werk en inkomen stellen daarnaast dat een overheersend repressieve beleidsaanpak onvoldoende effectief is. Nieuwe gedragseconomische inzichten worden als innovatief en kansrijk perspectief aangehaald om dit effectiviteitsgebrek tegen te gaan over de breedte van deze domeinen. Wel zijn er bepaalde populaire thema's, waaronder het stimuleren van beweging en gezond eten, het tegengaan van uitgaansoverlast, het verminderen van 'no-shows' van burgers bij gemeenteafspraken en het verminderen van zwerfafval.

Waar de lokale gedragspraktijk een breed toepassingsgebied bezit met tal van kansen voor keuzearchitectuur, is het de vraag of die kansen ook grondig benut kunnen worden in de praktijk. Van een afstand lijkt een dergelijke zorg onnodig; lokale gedragsexperts onderstrepen juist het belang van wetenschappelijke rigueur. Dat blijkt uit hun breed uitgedragen behoefte om opgaven wetenschappe- 
lijk, systematisch en volledig te analyseren op basis van krachtig causaal bewijs van 'wat werkt' (vgl. Lindbloms rational-comprehensive model (1959)). Dit rationalistische, evidence-based narratief is deels ook daadwerkelijk terug te zien in de praktijk, in het bijzonder in de vorm van diverse opgezette veldexperimenten. Een Amsterdamse gedragsexpert experimenteerde bijvoorbeeld met sociale normen in verkeerscommunicatie om rijden door rood licht te ontmoedigen. Het 'Nudge Netwerk Utrecht' experimenteerde in samenwerking met de Universiteit Utrecht met het aanpassen van de kantineomgeving om water drinken en staan (versus zitten) te stimuleren bij scholieren. En de gemeente Enschede voerde in samenwerking met een gedragsbureau een briefexperiment uit om de naleving van debiteuren te stimuleren. Diverse Nudge-technieken werden toegepast in een brief aan niet-betalende debiteuren, waaronder het presenteren van een sociale norm, het versimpelen en visualiseren van de informatie, en het reframen van informatie om zo negatieve emoties te voorkomen (bijv. niet spreken over 'achterstand'). Dit resulteerde in een relatieve stijging van 30\% meer debiteuren die actie ondernamen om iets aan hun schulden te doen (Janssen e.a., 2017).

Tegelijkertijd vormt het zuiver volgen van de evidence-based benadering een lastige opgave. Een respondent zegt hierover: 'Ik zou graag nog meer en grondiger de kennis [gedragsinzichten] toepassen dan dat ik nu doe.' In de praktijk ervaren lokale gedragsexperts veelal een spanningsveld tussen enerzijds wetenschappelijke rigueur en anderzijds haalbaarheid in de context van beleid. Gedragsexperts beschikken, zoals de vorige sectie al liet zien, over een beperkte hoeveelheid tijd, middelen en expertise. Bovendien opereren ze in dynamische beleidsomgevingen, waarbinnen de uitkomsten van hun acties lastig meetbaar of zichtbaar zijn te maken. Zulke beperkingen vragen in de praktijk vaak om het sluiten van compromissen tussen rigueur en haalbaarheid.

Een dergelijk compromis blijkt uit de observatie dat lokale gedragsexperts hun rigoureuze praktijk, gestut op experimentele evaluatiemethoden (in lijn met wat Aristoteles duidde als episteme; zie Parsons, 2002), deels vervangen door een 'zachtere' benadering, waarin ze leunen op een mix van andere methoden, zoals expertconsultaties, interviews, vragenlijsten, observaties, professioneel redeneren, creatief denken en praktijkervaring (meer in de richting van phronesis; zie Parsons, 2002). Deze zachtere benadering gaat gepaard met het ontwerpen en implementeren van tal van innovatieve en originele gedragsinterventies. Zo was een Utrechtse gedragsexpert betrokken bij de volgende reeks aan interventies: traktatieschalen voor basisscholen waarin traktaties met kleinere hoeveelheden op een aantrekkelijke manier worden aangeboden; 'groeikaarten', een serie kaarten die jeugdverpleegkundigen tijdens hun consult aan ouders kunnen meegeven, met korte en visuele uitleg over hoe kinderen bij dagelijkse bezigheden kunnen worden betrokken ten behoeve van hun cognitieve ontwikkeling; en concepten om op een speelse en intuïtieve manier gezond gedrag uit te lokken in het nieuwe stationsgebied, bijvoorbeeld een 'playful route' met allerlei spelelementen in de openbare ruimte en een 'positive sound' die de dagelijkse herrie overstemt. 
Een zekere mate van wetenschappelijke hardheid wordt dus ingeruild voor een snellere, zachtere en meer pluralistische bewijsvoering. De logica van wetenschappelijke rigueur komt in aanraking met een logica van snelle oordelen op basis van praktijkervaring en gezond verstand (Lindblom \& Cohen, 1979). Een Utrechtse gedragsexpert gaf bijvoorbeeld de voorkeur aan een 'pragmatische' werkwijze, gebaseerd op een voortdurend leerproces via snelle 'pilots', en werkte liever 'practice-based' dan 'evidence-based'. Hij beschouwde dit niet zozeer als het doen van een problematische concessie, maar eerder als een kwestie van 'gewoon de dagelijkse praktijk', waarin lang niet altijd wetenschappelijk onderzoek mogelijk of nodig is. Eenzelfde benadering is ook terug te zien in de zwembadcasus uit de veldnotitie, waarin BIG'R geen intensieve experimenten opzette, maar zich 'beperkte' tot literatuuronderzoek, observaties en gesprekken. Van daaruit werd gebrainstormd over slimme gedragsinterventies. Een voorbeeld waar nog sterker wordt ingeleverd op rigueur, komt van een geïnterviewde Utrechtse schooldirecteur, die expliciet afstand neemt van een wetenschappelijk-experimentele logica. Bij de aankomende verbouwing van zijn schoolgebouw past hij gedragswetenschappelijke inzichten toe vanuit een meer pragmatische logica. Handelen op basis van 'wat werkt' is voor hem vooral een kwestie van 'gevoel' (zie ook Feitsma, 2018b):

'Hoe mooi zou het zijn als we weten dat de kleur rood triggert om trap te gaan lopen, bijvoorbeeld. Hoe mooi zou dat zijn? Maar op een andere manier is dat ook een utopie en zou je dat inderdaad proefondervindelijk moeten vaststellen. Je zou het echt moeten doen. Het experiment. En op kleine schaal is dat misschien mogelijk, maar op grote schaal is het toch heel veel gevoel. Misschien is het dan wel dat je inderdaad... (...) wat literatuurstudies gaat doen. (...) Maar dan is het ook wel weer een kostenbatenverhaal. Dan denk ik: "Ja, er zijn nog wel veel meer dingen die heel erg interessant en heel erg leuk zijn." En voor mij is de winst alleen al een manier van denken die anders is geworden. En dat is genoeg.'

Het noodzakelijke compromis tussen rigueur en haalbaarheid wordt ook zichtbaar in het type projecten dat lokale gedragsexperts uitvoeren. Beperkte capaciteiten en de moeilijkheid om een dynamische beleidsomgeving experimentproof te maken dwingen hen vaak om te focussen op een select aantal haalbare projecten. Dit leidt ertoe dat bepaalde typen experimenten en gedragsinterventies prevaleren. Een voorbeeld hiervan, binnen het domein van zwerfafval, is dat diverse gemeenten in samenwerking met gedragsbureaus soortgelijke experimenten hebben uitgevoerd om bijplaatsing bij afvalcontainers tegen te gaan. Een andere populaire 'quick win' is het gebruik van keuzearchitectuur in overheidsbrieven, bijvoorbeeld gericht aan burgers met een openstaande schuld of aan bedrijven die actie moeten ondernemen rondom bouwvergunningen of onderhoudsverplichtingen. Keuzearchitectuur via brieven is populair, omdat aanpassingen in brieven vrij haalbaar, opschaalbaar en standaardiseerbaar zijn (John, 2018) en zich lenen voor experimentele toetsing. Ten opzichte van dergelijke informationele keuzearchitectuur worden fysieke vormen van keuzearchitectuur als minder haalbaar ervaren. De zwembadcasus maakt bijvoorbeeld duidelijk dat het herinrichten van 
de architectuur van gebouwen kostbaar kan zijn en weinig standaardiseerbaar lijkt. Ook default-omdraaiingen ogen minder haalbaar, aangezien defaults, in de woorden van een geïnterviewde, vaak 'dieper ingegraven zitten' in beleid.

Resumerend: de lokale gedragspraktijk oogt in ieder geval slagvaardig in de breedte. Casussen waarbij gedragskennis kan worden toegepast, zijn divers en talrijk. In de diepte lijkt de praktijk iets minder krachtig: gedragsexperts kunnen hun repertoire niet altijd even grondig inzetten in een incrementalistische omgeving vol beperkingen. Al schipperend tussen rigueur en haalbaarheid monden hun activiteiten dikwijls uit in 'quick wins' die elders al zijn beproefd. Er ligt ruimte voor het ontwikkelen van meer innovatieve projecten. Nochtans kan de manier waarop gedragsexperts weten te balanceren tussen rigueur en haalbaarheid ook worden gezien als kwaliteit. Het laat juist zien dat ze inspelen op de context van lokaal bestuur en zoeken naar duurzame aansluiting. Dat hun praktijk deels wordt omgevormd - in een poging te voldoen aan lokaal geldende beleidseisen zoals snelheid, zichtbaarheid en pragmatisme - wijst op hun vermogen om zich aan en daarmee ook in te passen.

\subsection{Politiek}

De focus van de analyse verschuift nu naar de politieke dimensie van lokale gedragsexpertise. Niet zozeer in termen van 'de politiek', zoals gemeenteraden en colleges van B\&W, maar in termen van 'het politieke': kwesties in het werk die omstreden (kunnen) zijn, tot conflict en zelfs strijd (kunnen) leiden en gedoe (kunnen) veroorzaken. Centraal staat de relatie tussen gedragsexperts en de buitenwereld, die bepaalde verwachtingen, wensen, bedenkingen en/of gevoelens heeft.

Een van de BIG'R-leden vertelt over de achtergrond van de zwembadcasus: 'Een collega kwam bij ons en dacht: "Laat maar eens even zien wat jullie kunnen. Lijkt me kansloos, geef maar een paar voorzetten, maar doe wat." En inmiddels zijn we ook gevraagd voor andere opdrachten. Bijvoorbeeld kijken naar het gebied rondom Feyenoord City. Daar gaat het om: je moet een paar verkoopbare successen hebben die men thuis aan de eigen vrouw en kinderen kan uitleggen.'

De Haagse gedragsexpert vertelt over haar zoektocht naar legitimiteit en middelen. Dat is volgens haar een 'kip-eiverhaal'. Ze heeft goede voorbeelden nodig om meer middelen te krijgen voor het toepassen van gedragskennis. Maar om zulke voorbeelden te realiseren heeft ze weer meer middelen nodig. Haar doelen zijn daarom 'quick wins' realiseren, kennis delen, en zorgen dat er echt draagulak komt. 'Zodat we meer tijd en ruimte krijgen en hier echt effectief op in kunnen zetten.'

Een gedragsexpert vraagt haar: 'Als je het hebt over commitment bij het bestuur, wie bedoel je dan precies? De directie-organisaties? Of het Stadsbestuur? Want hier (...) focussen we niet heel erg op de wethouders. We proberen het juist weg te houden van hen. We beschouwen dit echt als een instrument. Het zit in de gereedschapskist. Het is een vorm van bedrijfsvoering... en hoe saaier het klinkt, hoe beter het is...' 
Nadat de vergadering is beëindigd, lopen we met de groep het stadhuis uit, naar het Erasmus University College, waar BIG'R een publiek ethisch debat over gedragsinzichten heeft georganiseerd. Met als titel: 'Is BIG'R Brother nudging you? Ethische zoektocht naar een Rotterdams duwtje.' Het debat wordt ingeleid door een professor van de Erasmus Universiteit die is aangesloten bij BIG'R. De professor vertelt waarom dit publieke debat is georganiseerd: 'De grootste fout die we kunnen maken is het publiek niet op tijd meenemen in wat we doen. We moeten transparant zijn in wat we doen en zullen sowieso dat gesprek moeten voeren, want je hebt draagulak nodig bij de groepen waar je iets wil veranderen als je dat duurzaam wilt implementeren. Realiseer je ook dat het wel een heel erg krachtig team is: overheid en wetenschap die samen met elkaar gaan werken. Dat betekent dat we ook gecontroleerd moeten worden. Want het is nu eenmaal een hele krachtige alliantie.'

Bovenstaande veldnotitie laat zien dat de politieke dimensie van gedragsexpertise vooral een kwestie lijkt te zijn van legitimering: gedragsexperts willen duidelijk maken dat hun innovatieve denkwijzen van toegevoegde waarde zijn. Dat is in abstracte zin nodig om de eerder besproken positie en praktijken gemeentebreed 'gewicht' te geven. In praktische zin is het nodig om capaciteit te kunnen werven en daarmee de praktijk door te ontwikkelen. De ervaren bewijsdruk is in de veldnotitie terug te zien in een herhalende roep om 'verkoopbare successen'. Dat klinkt als marketingtaal, maar daarmee wordt overwegend het belang van succesvolle experimenten met gedragsinterventies bedoeld. Een dergelijk succesverhaal is het reeds genoemde briefexperiment dat de gemeente Enschede opzette om de naleving van debiteuren te stimuleren, met als resultaat een stijging van $30 \%$ meer debiteuren die in actie kwamen. Deze $30 \%$ stijging werd in de communicatie naar buiten als kernbevinding uitgelicht in een geprononceerd evidence-based narratief (zie Janssen e.a., 2017), dat, in de woorden van een respondent, hielp om de eigen werkwijze 'mee te koop zetten'. Een subtiele keuze in dit narratief was om de relatieve effectgrootte van $30 \%$ centraal te stellen in plaats van de absolute stijging van $11 \%$. Dit illustreert hoe gedragsexperts tactische keuzes maken in hun analyses, om zo hun verhaal naar de buitenwereld 'verkoopbaar' te maken. Daarbij maken ze gebruik van de overtuigingskracht van gekwantificeerde resultaten van veldexperimenten, zeker wanneer die gepresenteerd worden aan de hand van 'killer charts' (Stevens, 2011). Dergelijke resultaten kunnen verworden tot cruciale soundbites, die verdere beleidsbeslissingen bepalen - niet alleen om hun analytische inhoud, maar ook om hun eenvoud en elegantie (zie ook Feitsma, 2019).

De veldnotitie laat ook iets zien over het bestaande ethische debat over nudging (bijv. Leggett, 2014), en de wijze waarop dit 'leeft' in het veld. In het algemeen lijken lokale gedragsexperts weinig te stuiten op ethische weerstanden. Zelf stellen ze ook hun vraagtekens bij kritische normatieve geluiden - zeker de kritiek van burgermanipulatie achten ze ongeldig. Veelgenoemde weerleggingen zijn dat gedragsbeïnvloeding onvermijdelijk is en dat de overheid daarom maar beter de 'goede' kant op kan sturen, en bovendien dat gedragsinzichten transparant ingezet worden bij onomstreden beleidsopgaven (zie ook WRR, 2014). Ook vragen 
sommige gedragsexperts zich af of gedragsbeleid überhaupt een ethisch debat zou moeten oproepen. De gedragsexpert uit de veldnotitie bijvoorbeeld ziet zijn praktijk als een puur instrumentele hoedanigheid, die geen zaak zou moeten vormen voor politiek of moreel debat: 'We beschouwen dit echt als een instrument (...) en hoe saaier het klinkt, hoe beter het is...'

Op de achtergrond lijkt het ethische debat nog wel enigszins van invloed te zijn op het doen en denken van de lokale gedragsexperts. Ook al ervaren ze in hun eigen bestuurlijke omgeving weinig directe weerstand, ze zijn hier toch alert op en voelen zich genoodzaakt om een legitimerend tegenverhaal paraat te hebben. Alleen de mogelijkheid van weerstand kan de praktijk dus al op spanning zetten:

'Ik ben veel angstiger voor het framen van nudging als manipulatie. (...) In zijn column in de NRC heeft Bas Heijne ook wel een keer iets over nudging laten vallen als zijnde manipulatie. En ik las laatst van iemand anders ook in een artikel: "Ik wens niet door de overheid genudged te worden." Ik schrok daarvan. Dan komt het natuurlijk in een heel ander daglicht te staan. Daarmee wordt nudging negatief geframed door mensen die zich blijkbaar niet realiseren dat ze elke dag in de supermarkt genudged worden. Als je iets doet word je beïnvloed maar door iets niet te doen word je net zo goed beïnvloed. Zolang je de keuzevrijheid maar laat, is het wat mij betreft geen manipulatie. Maar je moet helemaal niet in die verdedigende rol terecht willen komen hiermee. Dat schiet niet op. Het is zo simpel om het negatief te framen. Daar moet je dus rekening mee houden. Dat is iets waar wij ook tegenaan lopen. Dat is ook praktijk.'

Slechts enkele keren lijken ideologische spanningen de lokale gedragspraktijk direct te beïnvloeden. Een respondent vertelde bijvoorbeeld op het terrein van armoedebeleid over zijn ervaren weerstand rondom plannen om te experimenteren met regelverzachtende Nudge-interventies in het voordeel van uitkeringsgerechtigden. Deze plannen werden niet gesteund door een overwegend rechts gekleurde gemeentecoalitie, waarin de eigen verantwoordelijkheid van de burger centraal stond. Een ander genoemd voorbeeld van een 'politiek gevoelige' gedragsinterventie is 'de jongerengeldautomaat': een project waar jongeren een aantal vragen over hun situatie op een soort pinautomaat konden beantwoorden, en vervolgens op een uitgeprint geldbiljet konden zien hoeveel geld zij jaarlijks misliepen, wat zij met dit geld konden doen, en waar ze financiële hulp konden zoeken. Deze campagne stuitte op weerstand vanwege de naam 'gratis geld', bedacht in samenwerking met de doelgroep en samenwerkingspartners, die de implicatie opriep van de gemeente als geldautomaat. Uiteindelijk is er voor een andere naam gekozen en is de campagne wel uitgevoerd. Uit beide voorbeelden wordt duidelijk dat de politieke weerstand niet zozeer gaat over de instrumentele aard van gedragsbeleid, maar eerder over de normatieve doeleinden waarvoor het wordt ingezet (zie ook Tannenbaum e.a., 2017).

Het gebeurt ook dat lokale gedragsexperts zelf het ethische debat expliciteren. Dit blijkt ook uit de veldnotitie, waarin een publieke discussie wordt georganiseerd 
Tabel 2 Kansen voor en grenzen aan de lokale gedragspraktijk

\begin{tabular}{|c|c|c|c|}
\hline Dimensie & Positie & Praktijken & Politiek \\
\hline $\begin{array}{l}\text { Empirische } \\
\text { patronen }\end{array}$ & $\begin{array}{l}\text { Verkennende fase } \\
\text { Beperkte capaciteiten } \\
\text { Overwegend decentrale } \\
\text { inzet van gedragsexpertise } \\
\text { Dilemma 'vindbaarheid ver- } \\
\text { sus eigenaarschap' }\end{array}$ & $\begin{array}{l}\text { Rijkheid aan gedragsopga- } \\
\text { ven } \\
\text { Sterk rationalistische ambi- } \\
\text { tie } \\
\text { Zachtere bewijsvoering in } \\
\text { de praktijk } \\
\text { Inzet op 'quick wins' } \\
\text { Dilemma 'rigueur versus } \\
\text { haalbaarheid' }\end{array}$ & $\begin{array}{l}\text { Focus op het bewijzen } \\
\text { van de eigen effectivi- } \\
\text { teit } \\
\text { Weinig direct ervaren } \\
\text { ideologische weer- } \\
\text { stand } \\
\text { Nadruk op ethische } \\
\text { reflectie en deliberatie }\end{array}$ \\
\hline $\begin{array}{l}\text { Doorwer- } \\
\text { king in ter- } \\
\text { men van kan- } \\
\text { sen en gren- } \\
\text { zen }\end{array}$ & $\begin{array}{l}\text { Geringe slagvaardigheid } \\
\text { door verkennende fase en } \\
\text { beperkte capaciteit } \\
\text { Veld presteert en ontwik- } \\
\text { kelt door ondanks } \\
\text { beperkte capaciteit }\end{array}$ & $\begin{array}{l}\text { Toepassingsgebied wordt in } \\
\text { de breedte benut } \\
\text { Deels onbenut potentieel } \\
\text { qua grondigheid en innova- } \\
\text { tiviteit } \\
\text { Veld gaat tactisch om met } \\
\text { tegenstrijdige beleidseisen }\end{array}$ & $\begin{array}{l}\text { Overwegend 'vrij spel' } \\
\text { binnen pragmatische } \\
\text { bestuurscultuur } \\
\text { Veld gaat tactisch en } \\
\text { zelfbewust om met } \\
\text { (mogelijke) weerstand }\end{array}$ \\
\hline
\end{tabular}

door BIG'R. De intentie van BIG'R om het gesprek met de burger hierover te blijven aangaan - 'De grootste fout die we kunnen maken is het publiek niet op tijd meenemen in wat we doen' - laat zien dat lokale gedragsexperts zich bewust zijn van het feit dat ze zich niet in een apolitieke ruimte bevinden, en juist doelbewust ruimte moeten inbouwen voor publieke deliberatie. Het organiseren van een ethisch debat wordt tevens als mogelijkheid gezien om expliciet en duurzaam draagvlak op te bouwen.

Samenvattend: de lokale gedragspolitiek lijkt vooral te draaien om het bewijzen van de eigen effectiviteit. Voor het veld is dit een comfortabele vorm van politiek, aangezien zij naadloos past in het discours van meer evidence-based beleid en verdere versterking van de 'krachtige alliantie' tussen wetenschap en beleid. Ideologische spanningen zijn schaarser en lijken meer op de achtergrond te spelen. Desondanks zijn lokale gedragsexperts zich bewust van (potentieel) conflict en springen hierop in door bijvoorbeeld zelf proactief het debat aan te gaan.

\section{Discussie}

\subsection{Concluderende bevindingen}

In dit artikel is de recente opkomst van gedragsexperts in het Nederlandse lokaal bestuur verkend aan de hand van drie dimensies - positie, praktijken en politiek. Tabel 2 vat de bevindingen per dimensie kort samen en denkt door op wat dit betekent voor de daadwerkelijke kansen voor en grenzen aan de lokale gedragspraktijk. 


\title{
Figuur 2 De gepercipieerde bijdrage aan gedragsbeleid van een ministerie
}

\author{
Wat heeft een ministerie te bieden op het gebied van \\ gedragskennis? \\ mentimeter
}

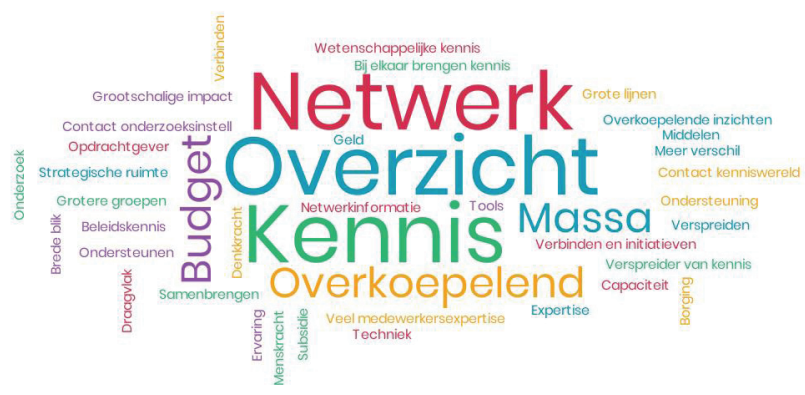

\subsection{Bijdragen aan gedragsbeleid vanuit verschillende bestuursniveaus}

Bovenstaande conclusies roepen een gemengd beeld op over de kansen voor de inzet van gedragsexpertise op lokaal niveau ten opzichte van het rijksniveau. Aan de ene kant lijken lokale gedragspraktijken minder kansrijk vanwege de relatief beperkte capaciteit op dit bestuursniveau. Het lokale gedragslandschap bestaat momenteel overwegend uit informele gedragseenheden met weinig personele en financiële middelen. Deze beperkte capaciteit lijkt ten koste te gaan van de grondigheid van de gedragspraktijk. De hoge mate aan wetenschappelijke rigueur die gedragsexperts ambiëren, is lang niet altijd haalbaar in de jachtige beleidspraktijk. Ze moeten voortdurend concessies doen op diepgang, rigueur en innovativiteit. Het gevaar is dat ze zich enkel wagen aan het behalen van reeds beproefde 'quick wins', waarmee de beleidsdiffusie die plaatsvindt beperkt blijft tot een minder leerzaam proces van imitatie (Shipan \& Volden, 2012). Een deel van de potentie van gedragsexpertise blijft daarmee onbenut. Deze kwestie weerspiegelt een breder bestuurskundig debat over de vraag of gemeenten wel afdoende bestuurskrachtig zijn, dat wil zeggen over de nodige middelen en kwaliteiten beschikken om hun taken succesvol uit te voeren (Boogers \& Schaap, 2007). Gemeenten hebben ten opzichte van rijksoverheidsinstituties een beperkt budget en kenniskapitaal, waardoor er minder ruimte is voor strategische innovaties. Hoewel externe samenwerkingen met gedragsbureaus en universiteiten kunnen compenseren voor dit gebrek, blijft dit bepalend voor de slagkracht van de lokale gedragspraktijk.

Hiertegenover bestaat er ook reden om te stellen dat gedragsinzichten juist toepasbaar zijn op lokaal niveau. Om te beginnen zijn lokale gedragsexperts nu al aan de slag met een rijkheid aan lokale gedragsopgaven. Dit brede toepassingsgebied vloeit deels voort uit het feit dat lokaal bestuur vraagt om het regelen van allerlei 
alledaagse zaken, zoals het schoon, veilig en bereikbaar houden van de stad (Barber, 2013). Het moeten volbrengen van die, zoals een geobserveerde gedragsexpert het noemde, 'aardse taken' verschaft in de praktijk een weelde aan gedragsopgaven. Die weelde kan bovendien goed worden benut, doordat lokale gedragsexperts vanuit hun nabije positionering tot de burger makkelijk als 'directe keuzearchitecten' (Feitsma, 2018a) kunnen interveniëren. Ten slotte duidt ook het gebrek aan direct ervaren politiek-ideologische weerstand op potentie. Hierdoor hebben lokale gedragsexperts de ruimte om hun inhoudelijke ideeën in de praktijk te brengen. Dit is in lijn met het idee dat op lokaal niveau een meer pragmatische en gedepolitiseerde bestuurscultuur heerst, hetgeen de bestuurlijke slagkracht vergroot (Barber, 2013).

\section{Figuur 3 De gepercipieerde bijdrage aan gedragsbeleid van een gemeente}

\section{Wat heeft een gemeente te bieden op het gebied van gedragskennis?

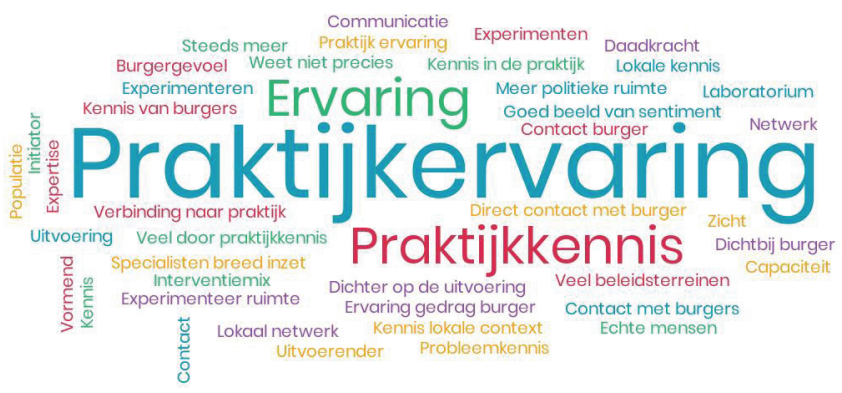

Dit gemengde beeld over de kansen voor gedragsbeleid op lokaal niveau ten opzichte van het Rijk kwam ook naar voren tijdens een workshop op de eerste 'Dag van het Gedrag', in november 2017 georganiseerd door BIN NL. Via een online enquête met 22 deelnemers werden woordwolken (zie figuur 2 en 3) gecreëerd over de bijdrage van de verschillende bestuurslagen aan gedragsbeleid. Daarin werd de inbreng van gemeenten vooral gelinkt aan hun nabijheid tot de burger. Gemeenten staan in direct 'contact met burgers' en beschikken over 'praktijkervaring', 'lokale kennis', 'zicht' en 'burgergevoel'. De inbreng van de ministeries wordt daarentegen eerder gelinkt aan hun capaciteiten en bredere strategische functie. Ministeries hebben 'budget', 'denkkracht', 'medewerkerexpertise' en 'strategische ruimte' om kennis te verzamelen, ontwikkelen, verspreiden en borgen. Deze brainstorm laat de verschillende typen bijdragen zien die bestuurslagen kunnen leveren aan gedragsbeleid.

\subsection{Meters maken: hoe dan?}

Hoe kunnen lokale gedragsexperts meer meters maken in hun proces van institutionalisering? Ik eindig met een drietal aanbevelingen hiertoe, die zich laten 
samenvatten door het kernwoord afstemming. Meters maken lijkt allereerst afhankelijk van de mate waarop een complementaire afstemming tussen bestuurslagen wordt gevonden in hun bijdragen aan gedragsbeleid. Waar centrale gedragsexperts een primaire rol als strateeg en netwerker beter past, kunnen gemeentelijke gedragsexperts gemakkelijker experimenteren met innovatieve technieken in de praktijk (zie figuur 2 en 3). Op dit moment lijken lokale gedragsexperts vooral nog actief in hun rol als kennismakelaar, bezig met het oprichten van intra- en interorganisationele netwerken, het ontwikkelen van relaties met externe partners (zoals gedragsbureaus en universiteiten), het verzamelen van goede voorbeelden en het verspreiden van gedragsinzichten (bijv. via lezingen, workshops en netwerkbijeenkomsten) (vgl. Feitsma, 2018a; 2018c). Deze kennismakelaarsrol past enerzijds bij de experimentele ontwikkelingsfase van lokale gedragsexpertise, maar anderzijds is het ook aan lokale gedragsexperts om van hun relatieve nabijheid gebruik te maken en aan de slag te gaan als directe kennistoepasser.

Het organiseren van onderlinge afstemming tussen lokale gedragspraktijken is daarnaast aan te bevelen voor een verdere institutionalisering. De huidige manier waarop het veld zich ontwikkelt, laat zich kenmerken door pluriformiteit - onder andere qua positionering (bijv. georganiseerd als gespecialiseerd team of juist als los netwerk) en praktijkbeoefening (bijv. rigoureus opererend of juist meer op 'gevoel'). Dit ontwikkelingstraject lijkt daarmee op een vorm van experimentalist governance (Sabel \& Zeitlin, 2012), waarbij overheden samen zoeken naar optimale bestuursvormen door in eerste instantie een diversiteit aan vormen te ontwikkelen, en deze vormen vervolgens te evalueren en bij te stellen (Scherpenisse e.a., 2016). Die zoektocht wordt, in de woorden van een Utrechtse gedragsexpert, verwoord als het 'dansen met gedrag'. Deze 'dans' is bij uitstek zichtbaar in het intergemeentelijk G6-overleg, waar veelvuldig werd gereflecteerd op de verschillende benaderingen. Het delen van ervaringen stond centraal, om op basis daarvan de eigen werkpraktijk zo nodig bij te stellen. Daarmee werd een productieve vorm van beleidsdiffusie via een proces van wederzijds leren mogelijk gemaakt (Shipan \& Volden, 2012). Zoals een Rotterdamse gedragsexpert zei: 'En als iets niet werkt? Laat het dan grandioos mislukken zodat anderen niet dezelfde fout hoeven te maken.'

Tot slot is in meer abstracte zin ook afstemming tussen tegenstrijdige beleidseisen aan te bevelen voor een succesvolle institutionalisering. Dit artikel heeft de kundigheid laten zien waarmee lokale gedragsexperts werkbare compromissen weten te vinden tussen schurende institutionele logica's. Hoewel ze aan de voorkant vasthouden aan de belofte van slim evidence-based beleid, wordt daarachter de praktijk 'vloeibaarder' en meer gericht op het duurzaam integreren in het gevestigde systeem. De beweging naar een zachtere bewijsvoering, die schippert tussen rigueur versus haalbaarheid, is hier een goed voorbeeld van (zie ook Feitsma, 2019). Het afstemmingsvermogen van lokale gedragsexperts toont aan dat hun werk niet enkel aandacht vereist voor nieuwe gedragseconomische inzichten in menselijk gedrag - ook al wordt het accent in het dominante beleidsidioom van 'met kennis van gedrag beleid maken' daar wel gelegd (WRR, 2014; cursivering JF). 
Hun werk vraagt juist ook om politiek-bestuurlijke vaardigheden: het tactvol kunnen opereren binnen een context van beperkingen, obstakels en tegenstrijdigheden. Het accent wordt daarmee verlegd in een richting die de praktijk niet alleen realistischer weergeeft, maar ook als advies kan worden meegegeven voor het maken van meters: gedragsexpertise als 'met kennis van beleid gedrag veranderen'.

\section{Literatuur}

@Marielle1972, 21 juni 2018. Tweet, gevonden op: https://twitter.com/NOS/status/ 1009460884865994756.

Algemeen Dagblad, Asofietsers Erasmusbrug buigen voor boegeroep en pijlen op de weg, 21 augustus 2018, gevonden op https://www.ad.nl/rotterdam/asofietserserasmusbrug-buigen-voor-boegeroep-en-pijlen-op-de-weg a1e416b0/.

Barber, B.R., If mayors ruled the world. Dysfunctional nations, rising cities, New Haven: 2013.

Benson, B., Cognitive bias cheat sheet, 1 september 2016, gevonden op https:// betterhumans.coach.me/cognitive-bias-cheat-sheet-55a472476b18.

BIN NL, Rijk aan gedragsinzichten, Den Haag: 2017.

BIT UK, Test, learn, adapt. Developing public policy with randomised controlled trials, Londen: 2012.

BIT UK, EAST. Four simple ways to apply behavioural insights, Londen: 2014.

Bonell, C., M. McKee, A. Fletcher, p. Wilkinson \& A. Haines, 'One nudge forward, two steps back', BMJ, 2011/342, p. 241-242.

Boogers, M.J.G.J.A. \& L. Schaap, 'Bestuurskracht: wat moeten we ermee? Een stand van zaken', Bestuurskunde, 2007/2, p. 5-14.

Feitsma, J.N.P., 'Brokering behaviour change. The work of behavioural insights experts in government', Policy \& Politics, 2018a, DOI: 10.1332/030557318X15174915040678.

Feitsma, J.N.P., 'The behavioural state. Critical observations on technocracy and psychocracy', Policy Sciences, 2018b/3, p. 387-410.

Feitsma, J.N.P., 'De makelaarsmachinerie achter gedragsbeleid', Christen Democratische Verkenningen, 2018c/2, p. 74-79.

Feitsma, J.N.P., "'Rationalized incrementalism”. How behavior experts in government negotiate institutional logics', Critical Policy Studies, 2019, DOI: 10.1080/19460171.2018.1557067.

Feitsma, J.N.P. \& T. Schillemans, 'Behaviour experts in government. From newcomers to professionals?', H. Strassheim \& S. Beck (eds.), Handbook of behavioural change and public policy, Cheltenham: 2019 (voorpublicatie via: https://papers.ssrn.com/sol3/ papers.cfm?abstract_id=3250352).

Hulst, M. van, 'Quite an experience. Using ethnography to study local governance', Critical Policy Analysis, 2008/2, p. 143-159.

Janssen, M., E. Bergsma \& K. Cooper, 'Positieve gedragsbeïnvloeding om inwoners te activeren. Eigen schuld ... of niet?', Sociaal Bestek, 2017/5, p. 37-39.

John, P., How far to nudge?, Cheltenham: 2018.

Kahneman, D., Thinking, fast and slow, New York: 2011.

Leggett, W., 'The politics of behaviour change. Nudge, neoliberalism and the state', Policy \& Politics, 2014/1, p. 3-19.

Lindblom, C., 'The science of muddling through', Public Administration Review, 1959/2, p. $79-88$. 
Lindblom, C. \& D. Cohen, Usable knowledge. Social science and social problem solving, New Haven: 1979.

Lodge, M. \& K. Wegrich, 'The rationality paradox of Nudge. Rational tools of government in a world of bounded rationality', Law and Policy, 2016/3, p. 250-267.

Madden, R., Being ethnographic. A guide to the theory and practice of ethnography, Londen: 2017.

Ministerie van Economische Zaken, Kabinetsreactie op adviesrapporten van Rli, RMO en WRR over de benutting van gedragswetenschappelijke kennis in beleid, Den Haag: 2014.

Ossewaarde, M.R.R., 'The new social contract and the struggle for sovereignty in the Netherlands', Government and Opposition, 2007/4, p. 491-512.

Paardekoper, C., M.L. van Genugten \& H. Wesseling, 'Eerste overheid in kruiend ijs - van bestuurlijke vernieuwing naar transformatie van de natiestaat?', Bestuurskunde, 2013/3, p. 45-52.

Parsons, W., 'From muddling through to muddling up. Evidence based policy making and the modernisation of British government', Public Policy and Administration, 2002/3, p. $43-60$.

Rhodes, R., P. 't Hart \& M. Noordegraaf, Observing government elites, New York: 2007.

Rouw, R., Gevoel voor bewijs, Den Haag: 2011.

Sabel, C. \& J. Zeitlin, 'Experimentalist governance', D. Levi-Faur (ed.), The Oxford handbook of governance, New York: 2012.

Scherpenisse, J., J.N.P. Feitsma \& T. Schillemans, Pluriform en passend. Het inbedden van gedragskennis in beleidsvorming, Utrecht/Den Haag: 2016.

Schillemans, T. \& G. de Vries (eds.), 'Gedragskennis in bestuur en beleid' (themanummer), Bestuurskunde, 2016/3.

Shipan, C.R. \& C. Volden, 'Policy diffusion. Seven lessons for scholars and practitioners', Public Administration Review, 2012/6, p. 788-796.

Stevens, A., 'Telling policy stories. An ethnographic study of the use of evidence in policymaking in the UK', Journal of Social Policy, 2011/2, p. 237-255.

Tannenbaum, D., C.R. Fox, \& T. Rogers, 'On the misplaced politics of behavioural policy interventions', Nature Human Behaviour, 2017/1, p. 1-7.

Thaler, R. \& C. Sunstein, Nudge, Londen: 2008.

Trommel, W.A., Gulzig bestuur, oratie Vrije Universiteit Amsterdam, Den Haag: 2009.

Tversky, A. \& D. Kahneman, 'Judgment under uncertainty. Heuristics and biases', Science, 1974/185, p. 1124-1131.

Website Behavioural Insights Group Rotterdam, www.bigrotterdam.nl, geraadpleegd op 9 april 2018.

White, M.D., The manipulation of choice. Ethics and libertarian paternalism, New York: 2013.

Whitehead, M., R. Jones, R. Lilley, J. Pykett \& R. Howell, Neuroliberalism. Behavioural government in the twenty-first century, Abingdon/New York: 2017.

WRR, De menselijke beslisser. Over de psychologie van keuze en gedrag, WRR-verkenning, nr. 22, Amsterdam: 2009.

WRR, Met kennis van gedrag beleid maken, WRR-rapport, nr. 92, Amsterdam: 2014.

WRR, Weten is nog geen doen. Een realistisch perspectief op redzaamheid, WRR-rapport, nr. 97, Den Haag: 2017. 